補緅誌, J Jpn Prosthodont Soc, 31 : 1553 1557, 1987.

\title{
咬合接触像のビジュアル化
}

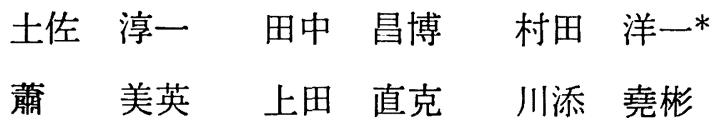

\section{Visualization of Occlusal Contacts on a TV Monitor}

Junichi Tosa, Masahiro Tanaka, Yoichi Murata*, Mei-in Shao, Naokatsu Ueda and Takayoshi Kawazoe

\begin{abstract}
This study presented the visualizing method of occlusal contacts by means of the digital image processing system.

Silicone-black method was frequently used to examine transparent areas as occlusal contacts in clinic.

Silicone-black (Bitechecker, GC Co., Japan) had two images, which were transparent areas and teeth surfaces. Each image through CCD TV camera was memorized in the digital processing system. And then the new image was obtained that markings of occlusal contacts were superimposed on teeth surfaces.

This method makes it valuable to examine occlusal contacts in number, location, intensity and area.
\end{abstract}

Key words : dental occlusion, image processing

\section{I. はじめに}

咬合診査，なかでも上下䫑歯の接触状態の把握は，歯 科補緅学において，䂭機能に関する基本的な診査の 1 つ である゙".チェアーサイドにおいて，咬合接触部の位置， 形状および面積を正確かつ詳細に，しかも簡便に診査で きることが切望されている.

ところで, 従来, 視覚的にとらえがたかったさまざ な事象が，近年の通信画像技術の発達により，モニタ画

大阪歯科大学歯科補緅学第 2 講座 (主任 : 川添堯颗教授)

* 大阪歯科大学大学院歯学研究科歯科補緅学専攻 (指導: 川添 堯倯教授)

The 2nd Dept. of Prosthetic Dentistry, Osaka Dental University (Chief : Prof. Takayoshi Kawazoe)

* Osaka Dental University, Graduate School, Major in Prosthetic Dentistry (Director : Prof. Takayoshi Kawazoe)

昭和 62 年 8 月 4 日受付
面上で観察できるようになり ${ }^{2,3)}$ ，そのビジュアルな効果 には絶大なものがあるといわれている，咬合接触状態に 関しても，このようなモ二タが可能となれば，臨床的な らびに診断的価値は非常に大きい。

われわれは，咬合状態において上下顎歯間に印象材を 介在させ，その印象面を TVカメラにより入力し，これ に種々の画像処理を施し，咬合接触部の位置，形状およ び面積を同時に診査することを目指してきた. その結果， 咬合面形態をリアルに画像化し，さらにこれに咬合接触 像を add 合成した画像をモニタ画面上に表示すること ができた. この画像を add 画像と称し，その処理につ いて報告する.

\section{II. add 画像処理法}

咬合状態において上下頡歯間に介在させた印象材に は，歯の形態の陰型と，咬合接触状態を示す印象材透過 部との $2 つ の$ 情報が含まれている. 本法は，それぞれの 


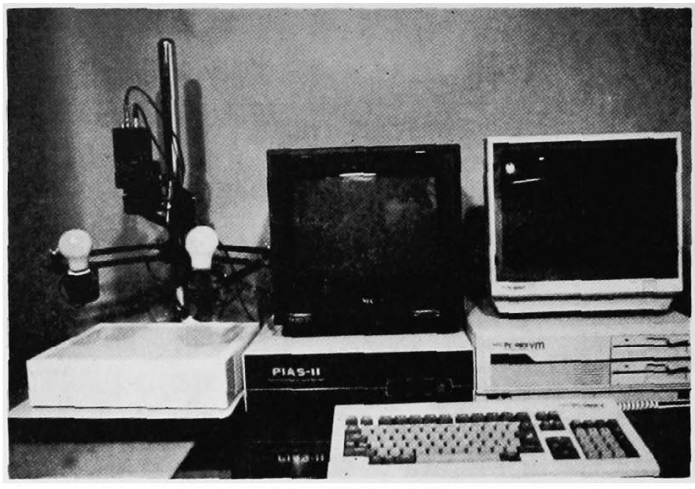

図 1 装運の全景

情報を印象面から TV カメラにより抽出し, 種々の画像 処理を施すものである，すなわち，咬合面形態を咬合面 像, 咬合接触状態を咬合接触部像として画像化し, これ ら 2 つの画像を合成寸ることにより，咬合面上に咬合接 触部のマーキングされた画像, 寸なわち add 画像がモ 二タ画面上に表示される. 同時に画像処理装置の画像計 測機能によりマーキング部の面積も測定できる.

以下，処理手順に沿って述べる.

\section{1. 画像処理装置}

本装置は, テレビカメラ，モニタテレビ，画像解析装 置 (PIAS 社, PIAS-II), パーソナルコンピュータ (NEC 社, PC-9801 VM), デジタイザー,インクジェットプリ ンター(SHARP 社, IO-720), および光源としてシャー カステンと白熱電球 2 つから構成される (図 1). テレビ カメラから入力した映像信号をリアルタイムに A/D 変 换し，画像解析装置のデジタル画像メモリに記憶する (画素数 $512 \times 512$ ). 記憶された画像を画素ごとに輝度レ ベル $0 \sim 63$ までの 64 階調に分け, パーソナルコンピュ 一タからのコマンドにより各種の画像処理および画素ご との画像計測を行い，その結果をモニタテレビに出力す る.

\section{2. 画像入力試料}

印象材には GC 社製バイトチェッカー®を用いた. 被 験者として, 歯周組織の健全な正常顎機能者で, 欠損歯 や転位，捻転歯のないものを選んだ．試料採得のため, 被験者の㐘列模型を用いて幅 $2 \mathrm{~mm}$ 厚さ $1 \mathrm{~mm} の コ$ の゙ ルトクロム線でバイトフレームを製作し，これを上顎左 右側犬歯間の唇面を覆うレジンシーネにて被験者の口腔 内に固定した. 同時に被験者に前方を直視させ, バイト チェッカー®をシリンジを用いて下顎歯列上に注入し，

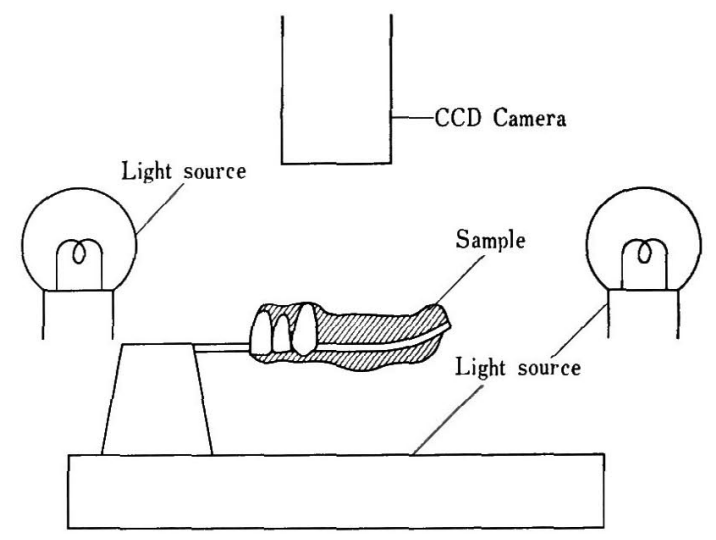

图 2 試料と光源扝よびカメラの位置関係

中心咬合位での中等度の咬みしめを指示した. 練和は標 準稠度で行い, 練和時間 20 秒, 練和開始後 40 秒で咬み しめを開始し, 咬みしめ時間は 60 秒とした.

採得したバイトチェッカー®を画像入力試料とし，バ イトフレーム把持部がシャーカステンと平行になるよう に固定装置に取りつけ (図 2), 画像入力に備えた, 把持 部と咬合平面はあらかじめ平行になるように調整してあ るので, 画像入力は咬合平面に対して常に垂直方向から 行われる.

\section{3. 画像入力}

1）咬合面像の入力

咬合面形態の陰型である印象面を, 白熱電球の反射光 下で入力する.これにより，咬合面の輪郭および各咬 頭, 小窝, 裂溝等の咬合面形態像が入力される, 図 3 に 入力された咬合面像の原画像を示す.

2）咬合接触部像の入力

咬合接触部に相当する試料透過部を，シャーカステン の透過光下で入力する. 図 4 に入力された咬合接触部像 の原画像を示す.

咬合接触部像の入力時には, 光源の輝度を一定にする ため, あらかじめ測定領域の光源のみを入力し, 各画素 の輝度のヒストグラムから, 輝度レベル 60 のものが全 画素の 50 パーヒントを超え, かつ輝度レベル 59 61の ものが 80 パーセントを超えることを確認し，その補正 は,カメラのしぼりにより行った.

1)，2）の入力は, 光源の電源を切り替えることにより, 同一試料に対してその位置を変えることなく行われる. 入力された原画像を，それぞれ画像解析装置のデジタル 画像メモリに記憶し, 以後の画像処理に備える. 


\section{4. 画像処理}

1) 咬合面像の処理 (図 5)

図 3 の原画像に輝度反転処理を行い咬合面の輪郭およ び各咬頭, 小窩, 裂溝等の咬合面形態を再現する.つぎ に低輝度強調処理によりコントラストを強調し, リアル な咬合面像とする.

2) 咬合接触部像の処理 (図 6)

図 4 の原画像にみられる画像透過部は, 資料の厚さに より輝度が連続的に変化するため, 境界が不明瞭となっ ている.このため, 任意の輝度において 2 值画像処理を 行い, その輝度以上の画素をすべて輝度レジル 63 に, 以下の画素をすべて輝度レベル 0 に変換する. つまり咬 合接触領域を黒の背景に白く抽出し, 境界を明確に設定 する. また，すでに，咬合時の上下顎歯間距離に相当す る資料の厚さとその透過光の輝度の間に対数回帰がなさ れている ${ }^{3)}$. 図 6 には, 咬合紙の厚さ約 $30 \mu \mathrm{m}$ 相当の 13 に 2 值化值を設定した像を示した. すなわち上下顎歯間 距離 $30 \mu \mathrm{m}$ 以下の領域が咬合接触部となる.

最後に, 得られた咬合面像 (図 5) と咬合接触部像 (図 6)を add 合成する.

\section{III. 画像処理結果 (add 画像)}

図 7 に add 画像を示す. 図 8 に, 同一被験者の同一部 位を咬合紙 (GC 社, Articulating Paper, 厚さ約 $30 \mu \mathrm{m}$ ) によりマーキングした像を示す. add 画像は, 咬合面の 輪郭および各咬頭, 小窩, 裂溝等が明瞭かつ立体的に表 現されている．また，咬合接触部が白い“ぬけ”の状態 で表現されているため境界が明瞭であり，その位置およ ぴ形状が各咬頭, 小窩, 裂溝等を基準として識別可能で ある.

一方, 図 8 では，5舌側咬頭や6 6 近心舌側咬頭内斜面 のマーキングが不明瞭であり，5遠心辺縁隆線中央部，

6遠心煩側咬頭頂付近に咬合紙の不要な接触によると思 われるマーキングがみられることから，マーキングが正 しい接触によるものかどうか識別が困難である.

このように add 画像は, 咬合紙によるマーキングと 比較し, 微小な接触領域も正確に識別できる.

しかも 6」，5」咬合接触面積はそれぞれ $5.1 \mathrm{~mm}^{2}, 2.6$ $\mathrm{mm}^{2}$ であることも診査できる.

\section{IV. 考察}

咬合診査の重要性は論ををたない. 主に咬合接触部の
位置, 形状, 面積が診査の対象となる. すなわち咬合接 触部の位置は, 対合関係の診査において重要であり ${ }^{4)}$, 咬合接触部の形状は, 咬合調整時に大切な診查項目であ $ろ^{5)}$. さらに, 咬合接触部の面積は, ブラキシズムなどの パラファンクションとの関倸からも診査される ${ }^{6)}$. この ためさまざまな咬合診査法が考案されてきた. その $1 つ$ であるシリコーン・ブラックによる診査法は，咬合紙7) のように歯や補綴物の表面性状や唾液などに影響される ことが少なく，咬合紙の移動による不必要なマーキング や“かすれ”が生じない. またシリコーン印象材の流れ がよいことから咬合を妨げることの少ない優れた方法で ある ${ }^{8)}$. しかし咬合面上の接触部の確認および面積の測 定には，従来は万能投影機上にて，歯列模型をトレース したものと, シリコーン・ブラック透過部をトレースし たものとを重ね合わせることが必要であり，客観性なら びに簡便さに欠けるものであった.

今回, このシリコーン・ブラックによる咬合診查法に 画像処理を応用することにより，咬合接触部の位置と形 状をビジュアルにとらえ，同時に咬合接触面積を測定す ることができる add 画像法を開発した.

add 画像処理の特徴のいくつかを列記すると，

1. 採得した試料を常に一定方向から直接画像入力で き，処理に要する時間は約 60 秒と短い．また画像をフ ロッピーディスクに保存し，随時モニタすることができ る.

2. 画像入力部であるテレビカメラには高 感度 CCD カメラを使用した.これは倍率を変えることにより全歯 列から 1 歯単位までの入力が可能である．またその高い 解像度により, 接触状態の微細な変化を追跡できる.

3. 咬合接触部像之咬合面像の入力は, 単一試料から 光源を透過光と反射光とに切り替えるのみで短時間に行 われるので, 試料の位置関係のくるいに伴う誤差は生じ ない.

そして，最も大きな特徴として，

4.上下顎歯間距離のどこまでを咬合接触領域とする かは研究者によりさまざまである現状において ${ }^{8,9)}$, 本法 は，2 值画像処理により上下頞歯間距離を任意に設定し, 咬合接触領城を自動的に抽出できる. このため真の接触 に近い咬合接触像から, near contacts ${ }^{9)}$ を含めた咬合接 触像まで単一試料から抽出でき，かつ領域設定に対して 人為的誤差が生じない. 例として, 上下顎歯間距離が 50 $\mu \mathrm{m}$ 以下, および $10 \mu \mathrm{m}$ 以下の範囲を咬合接触部像とし た add 画像を，それぞれ図 9 および図 10 に示す.

これらの特徵をもつ add 画像処理法に, 今後さらに 
$230-1556$

改良を加えるとともに，臨床応用を進める所存である.

\section{V. 結 論}

上下顎歯間に介在し咬合させたバイトチェッカー®に add 画像処理を施すことにより, 咬合接触部の位置, 形 状および面積を同時に診査できた.

本法を用いることにより, 咬合接触状態を口腔外で詳 細に観察することが可能となり, 今後, 咬合診查の場に おいて有用な手段になり得る.

なお本研究経費の一部は文部省科学研究费 (課题番号 61480412)によった.

本研究の要旨は昭和 61 年度日本補緅歯科学会関西支部学術大 会 (1987 年 2 月 11 日, 大阪) ならびに第 77 回日本補緅歯科学 会 (1987 年 5 月 29 日, 岩手) において発表した.

\section{文献}

1）石原寿郎, 藍 稔：咬合に関する見解の種々相, 3. 咬合
31 巻 6 号 (1987)

と歯の接触について，歯界展望，31：525 538，1968.

2) 藤井正道 : 画像彮断の適応とその選択, 日本医師会誌, 97 : $802 \sim 808,1987$.

3）村田洋一, 更谷啓治, 田中昌博, 川添堯森 : 画像解析によ る咬合診查, 日本医療情報学会第 1 回菌科医療情報システ 么研究大会論文集 : $37 \sim 40,1987$.

4）宮村一弘：上下䫟歯列の対向関係に関する研究（咬頭頂の 対向位固について), 補緅誌, $15: 322 \sim 349,1971$.

5）林都志夫：䫟運動とそのメカニズム，340 365, 日本歯科 評論社, 東京, 1977.

6) Jankelson, B. : Physiology of human dental occlusion, JADA, $50: 664 \sim 680,1955$.

7) Ramfjord, S.P. and Ash, M.M. : Occlusion, third edition, 305, W.B. Saunders Co.,Philadelphia, 1983.

8） 中尾勝彦：正常天然歯列における咬合小面と歯牙接触に関 する研究 (咬頭嵌合位), 補緅誌, $14: 1 \sim 21,1970$.

9) Philip, L.M. : A method to determine occlusal contact and noncorftact areas: Preliminary report, J Prosthet Dent, 52 : 106 110, 1984. 


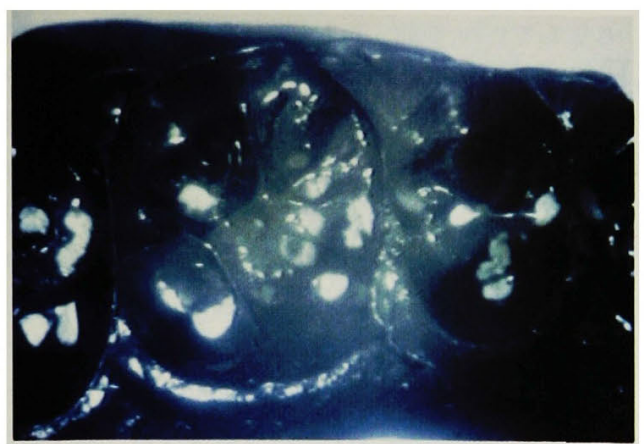

図 3 咬合面像の原画像 -

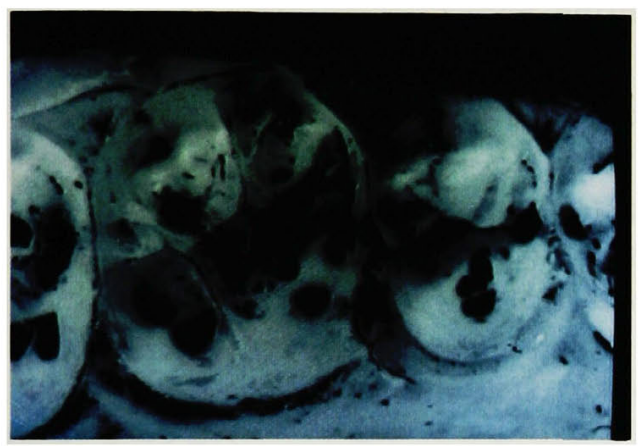

図 5 咬合面像

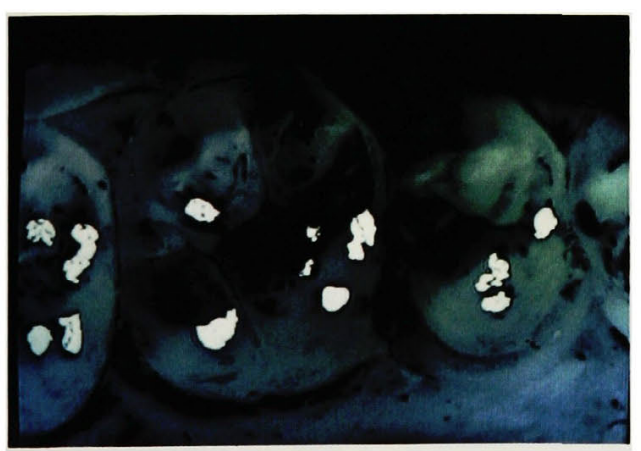

図 7 add 画像（上下䫁蒾間距離 $30 \mu \mathrm{m}$ )

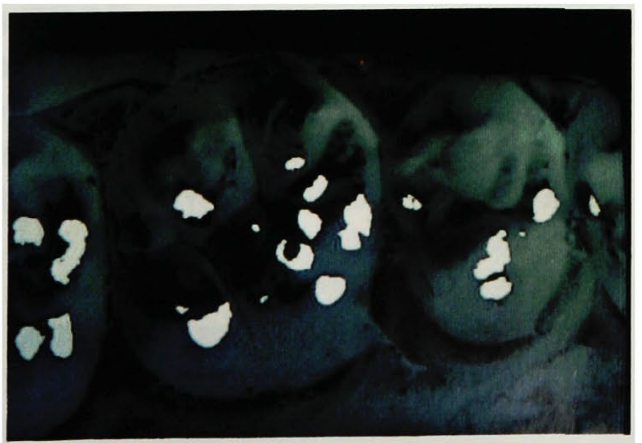

図 9 add 画像 (上下影菌間距離 $50 \mu \mathrm{m}$ )

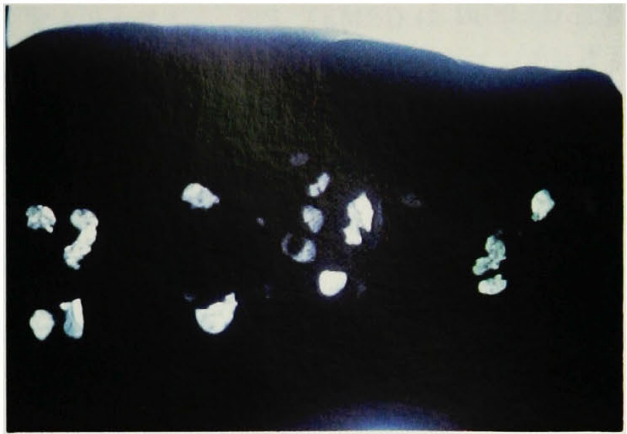

図 4 咬合接触部像の原画像

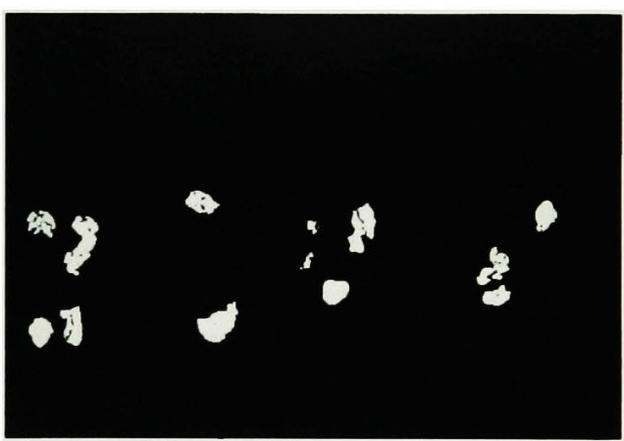

図 6 咬合接触部像 (上下滪歯間距離 $30 \mu \mathrm{m}$ )

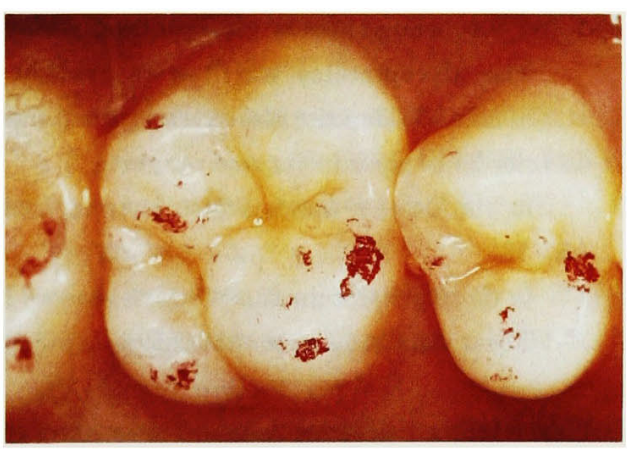

図 8 咬合紙 (厚さ約 $30 \mu \mathrm{m}$ ) によるマーキング像

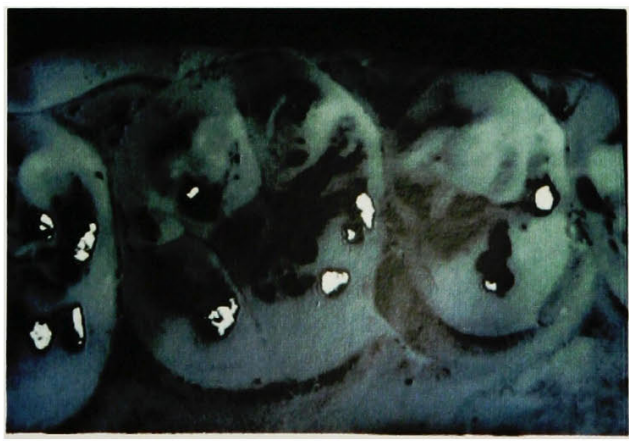

図 10 add 画像（上下顎蒾間距離 $10 \mu \mathrm{m}$ ) 